\title{
A NOVELIST READS THE TALMUD
}

AN INTRODUCTION

ONE EVENING, I WENT TO MY TALMUD CLASS. IT WASN'T a large class, maybe four or five men, but that night, for whatever reason, I was the only student there. I'd come to the study of Talmud relatively late in life, beginning in my mid-thirties. The Judaism I'd been served up as a kid had been a pretty thin gruel, and I spent most of my young adult life looking for wisdom elsewhere: in literature and art, in rock 'n' roll, in Eastern and Western philosophy, in mythology, in depth psychology.

Despite the richness I found in each of these, my hunger for meaning persisted, and - naïvely perhaps - I approached the Talmud, the repository of thousands of years of ancient wisdom, as a seeker might, crossing into its sacred precincts with the hope of finding a kind of livable transcendence there, a way of fusing the mundane hours of earthly life with a cosmic sense of holiness and wonder.

I was particularly interested in the stories - the anecdotes, allegories, fables, legends, and tall tales - in the Talmud's five thousand-plus pages. As a novelist, I spend my days steeped in stories. Stories are the doorway into meaning for me, the royal road into consciousness. Sacred stories even more so, I thought. My teachers, however, either skipped over these tales or sprinted past them quickly, and certainly they received none of the time and attention, the almost scientific dissection, we gave, as a class, to the Talmud's legal arguments.

I didn't share my teachers' reluctance to linger in these parts of the text, and I devised my own plan to study them. I decided to move through Ein Ya'akov (The Well of Jacob), the volume in which these stories are collected, starting with the section of the Talmud we were then studying in class. (The Talmud's 517 chapters are collected in 30-some sections usually called tractates in English.) The tractate was Bava Kamma (The First Gate), and the first story that piqued my interest there concerned a figure named Ulla. 
According to the story, when the daughter of a Babylonian rabbi dies, his colleagues decide to pay him a condolence call. They invite Ulla along, but Ulla will have none of it.

"What does your Babylonian method of consolation have to do with me?" he says to them. "It's completely blasphemous! When you all make a condolence call, you say, 'What can be done?'meaning 'What can be done against the will of the Holy One?'suggesting that if something could be done, you'd do it; and what is more blasphemous than that?"

Instead Ulla visits Rav Samuel on his own. Offering words of consolation, he quotes an oddly chosen passage from the Torah, reminding the bereaved father that "The Holy One said to Moses: 'Do not oppress Moab and do not wage war against them.'”

Now, if these words seem far from the point to the grieving father, it doesn't matter. Ulla is happy to elaborate upon them, and he sketches out a complicated argument involving the ancient Hebrew wars and the messianic future, and conversations between the Holy One and his prophet Moses, before arriving at his conclusion: "Were your daughter righteous and worthy of righteous descendants, she would have been spared."

I turned the page to read the conclusion of the story, but it ended there.

A STRANGE STORY by any stretch of the imagination.

Ulla, whoever he is - and all we know about him at this point is that he is not living, with his rabbinical colleagues, in Babylonia-refuses to join the local rabbis in paying a condolence call. Rejecting as blasphemous what we might understand as an expression of helpless compassion - What can be done? - Ulla visits Rav Samuel alone and essentially tells the poor man to look on the bright side: in the light of true piety, the death of this daughter is no great tragedy, and here is the sacred verse to prove it.

In the original Aramaic, with its Hebrew quotations from the Bible, the story is barely 150 words long. Still, it paints an evocative scene, its power deriving principally, I thought, from the extreme states of its protagonists: grief in the case of Rav Samuel, unyield- 
ing theological principle in Ulla's. Beyond this, though, the story supplies the reader with little help in its own decipherment.

In what at first blush appears to be a grand failure of imagination, our anonymous author doesn't even sketch in Rav Samuel's response. Though Rav Samuel's silence and Ulla's unchecked speech create in the reader an expectation of a dramatic reversal, that reversal never comes, and we're left on our own to imagine Rav Samuel's reaction, one that might fall anywhere along a broad spectrum of possibilities.

Missing, too, is the rabbis' response to Ulla's snub, a detail that might otherwise orient us within the moral geography of the story, although we can assume that no religious leader-certainly not one acting in accordance with the behavior of his peers-enjoys being charged with blasphemy.

On the other hand, great spiritual teachings are often counterintuitive and difficult to appreciate. Strip the story of its rabbinic inflections, substitute for Ulla the name Coyote or that of any other trickster figure, and it's not hard to read it as a mindstopping parable of nonattachment or Zen-like acceptance of life on its own terms.

Is Ulla a theological clown-in other words, are we meant to laugh at his antics? Or an unfeeling boor - should his treatment of Rav Samuel fill us with indignation? Or is he, perhaps, an enlightened master?

THESE QUESTIONS WERE very much on my mind when I arrived at my class and found myself the only student there. I mentioned the story of Ulla to my teacher. I told him that I'd begun reading the Talmudic tales, and that this story had me stymied right at the start.

"So you want to know what the story's about?" he said. "Well, since you're the only one here tonight, why don't we spend our class time looking into it?"

I followed him to the bookshelf, where he took down an exceedingly large volume of Bava Kamma. "This has all the notes in the bottom margin," he told me. "That's how we rabbis pretend to 
know everything." He opened the book and searched for the correct page. "Okay, here we go."

He sat at the table, the enormous book open before him, skimming through the story, while I sat expectantly at his elbow. He turned the page, twisting his beard in his fist. He turned back to the page before. He read the notes in the bottom margin. Finally, he slammed the book shut.

"Yeah, I have no idea," he said.

I TURNED NEXT to the classical commentators. Perhaps they might shed some light on this curious tale, but their commentaries, concerned principally with the application of sacred law, seem little interested in the character dynamics and the possible comic or tragic implications of Ulla's boorishness. Instead, they argue over the appropriate way of consoling a mourner.

Maybe reading the story in context, I thought, would help me understand it.

Along with the Bible, the Talmud is one of the foundation texts of Rabbinic Judaism. An ancient code of philosophical jurisprudence, it comprises two essential parts, the Mishnah and the Gemara. According to tradition, the Mishnah was revealed by the Holy One to Moses at Mount Sinai as an oral law accompanying and clarifying the written law, the Torah. One rabbinic legend asserts that the Holy One dictated the Torah to Moses by day and explained it to him by night.

This explanation is the Mishnah.

Passed down orally from generation to generation, the Mishnah was put into writing only around the year 3960 (200 CE) when, in the wake of persecution and exile, it was feared the oral teachings might be lost.

The Gemara, the other half of the Talmud, is a multigenerational metacommentary on the Mishnah dating from between 3960 and 4260 (200 and $500 \mathrm{CE}$ ).

I'm oversimplifying - a dangerous thing to do with a text as polymorphously diverse as the Talmud-but it seems to me that 
the Talmud weaves together three braided strands: the legal, the philosophical, and the legendary. The wide-ranging legal discussions of the rabbinic sages - known, in Hebrew, as the Halakhah (or the Way) - fill about three-fourths of the Talmud's five thousand-plus pages, and the Aggadah (literally, the Telling, the philosophical and legendary parts) the remaining fourth.

Among that fourth, salt-and-peppered into the text, sometimes in the Mishnah, sometimes in the Gemara, are stories about the lives of the sages, the holy men and mystics, who take part in the Talmud's theo-legal discussions.

(Imagine if, sprinkled within their legal decisions and dissenting opinions, the Justices of the US Supreme Court included anecdotes about their sex lives, allegorical fables about their travels, tall tales about their encounters with figures from American history-Abe Lincoln, Thomas Edison, Ethel and Julius Rosenbergand even their conversations with God, and you'll have some idea of the warp and weave of the Talmud.)

Though modern scholars may argue vehemently over the precise literary structures of the Talmud, there's a working assumption, although it might not always be clear how, that a piece of the Gemara is related thematically to the part of the Mishnah it intends to illuminate.

One might therefore assume that reading the story of Ulla and Rav Samuel in the context of its placement in the Talmud might reveal something about the story's deeper meaning. Doing so, though, only raised more questions than it answered.

Ulla's story appears in a part of the Talmud concerned with cases of damages, specifically with goring oxen across social classes (i.e., what happens when an ordinary Israelite's ox gores an ox belonging to the Temple or when an Israelite's ox gores the ox of a Canaanite).

NOW I WAS more confused than ever.

Are the Talmud's editors hinting, subtly or unsubtly, that Ulla is the social equivalent of a goring ox? Is his story an example of 
violent speech? Or is his refraining from blasphemy the opposite of violent speech? Will he be rewarded by Heaven for how he speaks to Rav Samuel or rather denied a reward for it?

In either case, I was no closer to answering the fundamental questions the story presents, not as part of a legal discussion, but as a meaningfulfiction: Who is Ulla? Is he a hero or a villain? Should we, his audience, applaud his refraining from blasphemies, or is his worldview, when the rubber meets the road, as absurd and as cruel as it, at first blush, seems?

And finally: what do we learn about the world and ourselves from this sacred fiction?

FOLLOWING ULLA DOWN the rabbit hole, I began pulling together as many stories as I could find concerning him, and I discovered a curious thing. As a literary figure-as a figure made out of words (who can vouch for the historical man?) - Ulla seems to possess a small number of traits and a distinct personality, and he appears to be involved in a single story, a single drama concerning his trip from the Land of Israel to Babylonia, a drama that ends with his tragicomic death.

And drama is the correct word.

These tales - though often anecdotal and fragmentary-are unvaryingly dramatic in form. Like a stage play, they're written as scenes, playing out in an eternal present tense; the characters, lacking almost all interiority, must speak their rare private thoughts aloud in soliloquies; the narrator, employing the simplest of voices and vocabularies, restricts himself almost always, as a playwright does in his stage directions, to things that can be seen or heard; the scenes adhere to the classical unities of time, place, and action, as well.

As I plunged into these tales, I began to wonder, what mosaics would appear if the various scenes - scattered in so many pieces across the Talmud and the midrashic literature-were brought together? Would they form a larger drama, a greater narrative with consistent characters, a sustained storyline, and a coherent system of imagery? 
This seemed to be the case, and I seemed at last to have found the key to unlocking the door into these tales, at least for me. In the years I've spent studying and teaching these stories, I've discovered that obscure elements in one fragmentary scene often illuminate elements in another, revealing a veritable rabbinical comédie humaine, replete with every recognizable type and variation of Homo spiritus.

Sometimes wild, sometimes rude, sometimes bawdy, though employing simple means, these are not simple stories. Like much ancient sacred literature, they often fly in the face of our conventional notions of piety. The holy men depicted in the Talmudic tales are clearly holy. No one is disputing that. According to tradition, to even be mentioned in the Talmud, one had to be able to raise the dead. Still, the saints and sages in these stories are often depicted as flawed and tragic figures, only-too-human, after all, despite their high attainments in the sacred spheres. This is only right, I think, and honest. In the rabbinic imagination, the creation of holiness is a human, and not a superhuman, endeavor. As the poet Wallace Stevens reminds us, the way through the world is more difficult to find than the way beyond it. And one can learn as much if not more, I suspect, from a great person's flaws than from his accomplishments.

RABBiniC COMMENTATORS FROM the Middle Ages to the present hour, reading these stories primarily as history, have tended to explain away the miracles, the unrealism, the fantastical elements, while bowdlerizing the morally difficult and bawdy parts. Modern academic scholars, on the other end of the spectrum, though unafraid to take the unvarnished measure of these tales, are seldom concerned-professionally at least-with the question of how these stories speak to the reader's most pressing human needs.

A novelist, however, is able to live in the vale between these two opposing and imposing camps. An imaginative writer's concerns are different. A storyteller is interested in the arresting, the stirring, the provocative; with what lifts the heart, quickens the pulse, 
and stirs the soul. Literature, after all, is meant to transform us, sacred literature even more, and so why not analyze and interpret these stories as a novelist would? They're fictions, after all, though fictions in the most profound sense of the word. They work the same way profound fiction works: while delighting us through our childlike love of stories, they attempt to express something essential about human life.

The chapters that follow are an imaginative and personal response to this sacred literature. My readings of these tales are, I know, wildly subjective, idiosyncratic, and far from definitive. These stories seem inexhaustible to me, and I know my interpretations, no matter how full, can only be partial.

Still, I've done my best to explore these stories as deeply as possible, to shine some light on this brilliant, beautiful, and strange body of literature, and to contribute whatever I can to the discovery and recovery of the beauty and depth they offer us as meaningful fictions.

ONE FINAL NOTE: As I said earlier, I've come to think of these stories, as an imaginative conceit, as memos from an unnamed writer, an Aggadist, a master of Aggadah, a teller of tales, working in the hinge-time between the fourth and fifth millennia on the Hebrew calendar. Each of the following chapters is preceded by the memo, the story under discussion, unadorned by commentary, so that the reader may encounter it in its original state. 